\title{
Personal-ethical perspectives in the work of Etienne de Villiers
}

\author{
Author: \\ André C.J. van Niekerk ${ }^{1,2}$ \\ Affiliations: \\ ${ }^{1}$ Department of Dogmatics \\ and Christian Ethics, \\ University of Pretoria, \\ South Africa \\ ${ }^{2}$ Dutch Reformed Church \\ Waterkloof, Nieu- \\ Muckleneuk, Pretoria, \\ South Africa \\ Correspondence to: \\ André van Niekerk \\ Email: \\ andre@waterkloofkerk.co.za \\ Postal address: \\ PO Box 75125, Lynnwood \\ Ridge 0040, South Africa \\ Dates: \\ Received: 19 June 2012 \\ Accepted: 19 Sept. 2012 \\ Published: 06 Dec. 2012 \\ How to cite this article: \\ Van Niekerk, A.C.J., \\ 2012, 'Personal-ethica \\ perspectives in the work of \\ Etienne de Villiers', Verbum \\ et Ecclesia 33(2), Art. \#753, \\ 6 pages. http://dx.doi.org/ \\ 10.4102/ve.v33i2.753
}

C) 2012. The Authors. Licensee: AOSIS OpenJournals. This work is licensed under the Creative Commons Attribution License.
With a mixture of hesitation and gratitude, the author undertook a reflection from a pastor's viewpoint on Etienne de Villiers's personal-ethical contributions to date. The distinguishing term 'personal' in 'personal ethics' is problematic, but the discussion thereof provided an opportunity to demonstrate that De Villiers did not develop a narrowed individual ethic, and decidedly also did not elect to take the route of Dilschneider's 'personal ethics', but provided valuable contributions on ethical issues of a more personal nature. De Villiers's greatest contribution concerns fundamental ethics which, viewed from the perspective of our history, as well as from our current situation, is now most essential for authenticity. This more fundamental focus on ethics has numerous implications for social ethics and also for more personal ethics.

\section{A courageous person's moral teaching}

'It is not good to have zeal without knowledge, nor to be hasty and miss the way' (Pr 19:2).

My reflection on the work of Etienne de Villiers has helped me to realise with greater clarity how, in my own life and work, he has - as probably with many other pastors - in a quiet yet incisive way, through his doctrine and his courage - indeed, his personal integrity - urged us to bring home more courageously, and hopefully also in a more nuanced way, an ethical doctrine and moral development to congregations and community institutions such as schools. For example, does it not demand courage to go to the Free State and speak about the church's approval of homosexual marriages? (De Villiers 2006a). This type of fearlessness is confirmed when he warns against passivity in his guidelines for a sermon on patience as a virtue (De Villiers 1996). He accepts Walter Wink's exegesis on Jesus' third (nonpassive) way (De Villiers 1989:124). De Villiers reminds us in a number of ways that we have a responsibility; however, with him, this involvement and zeal, as in the quotation from Proverbs above, is not over-hasty, but well considered.

\section{Evaluation after the water has broken ...}

I am not reviewing De Villiers's ethics in typical academic fashion in this article, but as a pastor belonging to the same church, to which we are both 'critically loyal' (to use Prof. Johan Heyns's refrain). Indeed, understanding this critically loyal stance became all the more important when, at various points during his ministry and career within this church, De Villiers called the church's morality into question. In his articles on the role of the Dutch Reformed Church (Nederduitse Gereformeerde Kerk, abbreviated as NGK, henceforth referred to as the DRC) in the establishment and maintenance of apartheid (e.g. 'Criticism from the ecumenical community' and, more recently, in the 'The interdependence of public witness and institutional unity in the Dutch Reformed family of churches'), De Villiers $(1986,2008)$ indicated, amongst other things, that the DRC subscribed to a 'pseudo-religious ideology or secular gospel that is contrary to the gospel of Jesus Christ' (De Villiers 1986:152, own translation).

During 2011, the year after De Villiers's formal retirement, the DRC has made significant advances in its resolutions concerning Belhar, church unity, reformed identity and other matters. An attentive observer, Frederik Marais, describes the surprising and overwhelming acceptance of Belhar as breaking the water of the new church! On many occasions I have heard from members and ministers that, for the first time in a very long time, we can be proud of our synod's courage and leadership. For my part, I realised that, for the first time, it was easier to report on a synod to the youth and teenagers than to the older members.

What would be the reasons for this change in climate and resolutions? The season of listening [seisoen van luister] in the DRC is the first. This season is embedded in a spirituality in which questions about God (e.g. What is God up to? What do we think God wants from us now?), listening to the Bible and one another, as well as discernment practices, are of vital significance. 
In support hereof, and even giving rise thereto, are the contributions of De Villiers, other lecturers and opinion shapers who have, over decades, drawn attention to authenticity, church unity, confession and religious discrimination. To repeat but one of De Villiers's conclusions:

Instead of making over-hasty decisions that will merely drive members even further into [opposing] camps, they should strive instead to cultivate a culture of dialogue and mutual tolerance on matters such as homosexuality. (De Villiers 2007b:288, own translation)

It was noticeable how many young participants were present and played a role at the synod. One such participant was a young female minister holding a baby in her arms. She stood with her child before the synod and pleaded for the acceptance of Belhar, 'so that my child can have a church one day ...' (own translation). It is images and symbols such as this that stir people today more than words.

The new approach to ethics education, prophetic convocations and penetrating arguments in addresses, press commentaries, interviews, articles, sermons and meditations by De Villiers and other colleagues probably contributed to the positive regard for Belhar. A new, credible theological climate and a church culture have been established. Remember also that De Villiers is the promoter of the new synodal chairman, Nelus Niemandt, under whose leadership the abovementioned changes and resolutions were made.

It would probably be premature to conduct a thorough investigation of the hypothesis that the theological training of recent decades has led the way to a new acceptance of faith and church unity. In his fourth volume on the history of the church, Praamsma (1981:9) uses the image of viewing a street scene to explain that we are, as yet, unable to gain a proper perspective on the recent historical period. We do not stand on a high balcony with a view over the street - we see only fragments; we are still amongst the milling masses in the street.

Despite all these reservations, I would nevertheless venture to claim in the language of faith that De Villiers's ethics formed part of a set of contributions that the Lord used to lead religious communities to a new social dispensation; encouraging us to put into practice this authentic testimony in this new situation by embodying church unity, fulfilling our prophetic role in modern society and practicing an ethic of responsibility. What then is De Villiers's contribution to personal ethics?

\section{The problematic definition of the term 'personal'}

The term 'personal' can be understood in various different ways. Two sets of approaches which are particularly significant in terms of my brief overview will be discussed in the subsections to follow.

\section{'Personal' ethics as opposed to 'social' ethics}

'Personal ethics', according to Chris Jones (2008:318, own translation), 'in fact has no generally accepted and technical meaning within the broad field of Christian ethics'. When the distinction is nevertheless made, it could denote either personal responsibility in moral conduct or interpersonal relationships, as opposed to 'social ethics'. To reinforce this, D.A. du Toit (2008:320, own translation) understands personal ethics as concerning 'individual ethical decisions' and social ethics as concerning 'decisions beyond the individual, those of social institutions and structures'. However, Du Toit warns against making a sharp distinction.

Klaus Nürnberger (1984:6-9) divides his discussion of the steps in the process of moral judgement between personal ethical problems (e.g. 'Should I participate in the strike?'), structural or transpersonal ethical problems (e.g. 'Which economic model should we implement?') and fundamental ethical problems (e.g. 'What do "duty", "responsibility" and "courage" mean?').

J.A. Heyns (1986) refers, amongst others, to W.D. Jonker, who approaches the morality of human relationships from two viewpoints:

Personal ethics concerns the moral conduct of the individual who concretely encounters his fellow human beings in the thousands of situations in which people have personal dealings with one another and are required to honour, serve and care for them as people. This concerns the personal relationships with 'undefined' fellow human beings. Social ethics, on the other hand, concerns the relationship between people from the point of view of their encounter with (or accompaniment of) one another within the cadre of certain objective relationships in which they are placed by the fact that they encounter one another as members having a certain community context. They are 'defined' fellow human beings. (Jonker, in Heyns 1986:8, own translation)

To Heyns (1986:1-10, own translation), individual or personal ethics studies 'man's actions as an individual being', whilst social ethics studies 'man's actions as a social being'. In his first volume on ethics, Heyns (1982:356-357, own translation) already distinguishes individual ethics as being ethics concerning the 'intrapersonal I-I relationship', and social ethics as ethics that concerns the 'interpersonal I-you, I-you (pl.) or we-you (pl.) relationship'. Under social ethics, Heyns treats matters such as marriage, sexuality and homosexuality (1986:132-188), abortion (as a subsection of family planning) (1986:213-218) and medical ethics, including euthanasia and ethical norms for medical experiments (1986:324-334).

\section{'Personal' ethics as distinct from 'actual' ethics}

In connection with a narrow understanding of the Gospel of theliberal theologists, Troeltsch and Naumannand, especially, Dilschneider's preference for 'personal' ethics, Dietrich Bonhoeffer (1995:316-326) based his understanding of the comprehensive task of responsibility ethics on Christological principles. Otto Dilschneider limited 'protestant ethics' to personal ethics. The implications of which are that Christian ethics concerns the Christian economist and the Christian 
politician, but not economics and politics per se, which would be ethically neutral. In terms of this, the church would have the task of inspiring institutions and caring for their victims, but not the task of correcting world orders and advocating new world orders.

\section{According to Bonhoeffer (1995):}

The New Testament cannot conceive of a proclamation to the world without testimony to Christ, i.e. without the only solid basis for such a proclamation. Consequently the decisive responsibility of the congregation for the world is always the proclamation of Christ. (p. 319)

Liberal theology's 'God and the soul', as opposed to the socialists' 'God's kingdom on earth', are false contradictions. The central message of the New Testament is that Jesus Christ is the saviour of the world. All things were created through him and for him and exist in him (Col 1:16). In him all is reconciled with God (2 Cor 5:19) and all things are united under one head, Christ (Eph 1:10). In Christ, God loves the world (Jn 3:16). All that exists does so under, and for the sake of, Christ. Everything belongs together, and we dare not arbitrarily take it asunder. Bonhoeffer (1995:322), in his criticism of Dilschneider, writes, 'Christ does not detach the person from the world of things but from the world of sin; there is a great difference'. Thus everything falls under Christ's dominion and God's commandments. We dare not make a distinction between people and things, but only between the congregation and secular institutions.

According to the essential nature of the congregation, the congregation is responsible for the whole world, which God in Christ loves. Christians bear this responsibility towards secular institutions so that they can fulfil their true 'worldliness'. How this task of representing God is to be performed depends on the character of a specific era.

\section{Did De Villiers develop a personal ethic?}

Given the problematic definition of 'personal', the answer to whether De Villiers actually developed a personal ethic is conflicting. Thus, I offer two variations below: one in the negative concerning the two ways of understanding 'personal', the other in a qualified affirmative.

\section{No, De Villiers's focus is on fundamental and social ethics}

In the sense of the initial understanding of 'personal' above, as in Jonker's definition as the moral conduct of a person towards the undefined fellow human being, or in Heyns's contention that it concerns the intrapersonal and I-I relationship, it is my conclusion - admittedly based upon my limited observation - that De Villiers did not develop such a 'personal ethic'.

In the sense of the second understanding of 'personal' above, such as that of Dilschneider and other Lutherans, De Villiers also did not promote such a 'personal' ethic. In fact, one of
De Villiers's strongest characteristics is precisely that he, in typical Reformed fashion, has emphasised and championed involvement in the world. To give one example (which we as pastors currently need for defending and explaining Belhar):

In emphasising the public witness of the church the Belhar Confession remains faithful to one of the central convictions of the Reformed tradition, namely that the church is called by God to contribute to the transformation of society ... This conviction is based on a belief that is equally central to the Reformed tradition: God the Creator and Governor is also Lord of history ... (De Villiers 2008:729)

\section{Yes, De Villiers promotes ethical issues of a more personal nature}

In writing this overview, I realised that 'personal ethical motives' may refer to medical and sexual ethics. De Villiers (2006a:56, my emphasis, own translation) writes that the new political dispensation has liberated ethicists from a one-sided concentration on social-ethical issues (apartheid, security) in order to give attention to 'other burning ethical questions of a more personal nature, for example homosexuality, abortion and euthanasia'. Elsewhere, in the same year, De Villiers (2006b:78) mentions the possibility that the DRC's General Synod did not react to the abortion legislation of 1996 because there were simply too many urgent matters to attend to after the implementation of the new political dispensation.

What follows, then, is an overview of De Villiers's stance on a number of ethical issues of a more personal nature facing the church today.

\section{Ethical aspects in De Villiers's reflection on homosexuality}

In my opinion, De Villiers's significant contribution concerning the issue of homosexuality was that he assisted churches and believers in the process of discernment and becoming more accountable in their judgements. Of great religious significance is that, concerning hermeneutic conflict, De Villiers turned around the tendency of recent years to preach what the Bible does not say by focusing on moral orientation, which the Bible indeed provides (De Villiers 2006a, 2007b).

De Villiers's outspoken empathy with members who had become confused by theologians' opinions and synodal resolutions, who were experiencing various transitions and adaptations and thus needed clear Scriptural guidance, did not result in retreating into fundamentalism, or concluding that the gap between contexts means that the Bible actually has nothing to offer on current issues. Both the historical nature of the Bible and the uniqueness of our new context should be respected. In fact, it was probably De Villiers's priestly compassion that helped others to be able to hear his prophetic voice. In our mutual dialogue we are able to discover lasting ethical guidelines and values for intimate relationships, amongst others, loyalty, mutual respect, dedication and mutual service.

De Villiers also addressed the prejudices and emotions - of both a negative and positive nature - associated with the issue, including the tendency to feel that the causes 
of homosexuality, whether nurture or nature, would be the decisive factor, as well as with the traditional view of sexuality (for the purpose of procreation) and marriage (De Villiers 2007b).

De Villiers (2006a:69-75, own translation) demonstrates that the arguments based upon natural law in the Reformed tradition do not carry much weight. For this reason, and following the scriptural moral orientation and especially Christ's example, he is able to support the wish of those who are essentially homosexual to enter into permanent relationships. Here De Villiers becomes concrete without being prescriptive. He chooses a compromise that will not harm the traditional understanding of and sentiments concerning marriage, referring to it as a 'homosexual lifelong bond', meaning that it should be solemnised by way of a church ceremony and that the church should support the legitimisation of such marriages.

\section{Ethical aspects of De Villiers's reflections on cloning}

De Villiers's (1998) significant contribution to the issue of cloning is that he indicates that a deontological evaluation from existing norms (such as the uniqueness of human life and the artificial creation of life) does not adequately take into account the complexity and contradiction of the issue. In addition, such an evaluation is often linked to religious anxiety regarding new discoveries. Currently, all the results of the techniques cannot be viewed clearly (in a theological evaluation) and therefore we should not reject them unconditionally.

From a Reformed ethics point of view, we should rather warn against the following real dangers: physical (the death of embryos during experiments), destruction of the personal dignity of children (ordering children from a human factory to suit personal taste), undermining of marriage and the family (a fanatical insistence upon one's own genetic material that is then loved conditionally), as well as the further neglect of orphans and street children (money and attention spent on expensive technology instead).

\section{Ethical aspects of De Villiers's reflection on abortion}

In my opinion, De Villiers's (2006b) most important contribution to the issue of abortion is that he points out the more subtle nuances in ethical judgements and also how such ethical issues should be dealt with within the new churchstate relationship. (The latter aspect is surely not any form of 'personal' ethics - which once again merely illustrates the artificial divide and the interwovenness of ethical aspects).

Although De Villiers agrees with the DRC's official 1982 viewpoint of predominant rejection, he posits that the DRC's ethical arguments are inadequate. Instead of adhering only to the viewpoint that human life begins at conception, it should rather be acknowledged that scientists are in disagreement and that the status of a foetus as a self-conscious human being indeed differs. Based on God's particular caring for the weak, the life of a developing person, whether in embryonic or foetus form, must be protected. In rejecting the circumstances that justify abortion, the DRC's views tend to harp on the abuse of the circumstances, instead of acknowledging the ethical dilemmas and complexities, for example when a woman is raped and becomes pregnant.

De Villiers differs radically from the DRC's assumption that the rejection of abortion by one religious denomination on Christian ethical grounds is reason enough for the state to declare all forms of abortion to be illegitimate. De Villiers (2008) follows Gerrit de Kruijf's double process of ethical reflection on issues such as abortion by applying Walzer's distinction between 'thick' and 'thin':

Walzer utilizes the term 'thick' to point to a kind of moral argument that is 'richly referential, culturally resonant, locked into an established symbolic system or network of meanings'. 'Thin' is simply the contrasting term. (De Villiers 2008:740)

In the 'thick' process of Christian morality, abortion is rejected in terms of Christian ethical principles; Christians are encouraged to distance themselves from it and to guard against diluting this particular moral stance. In the 'thin' process, non-Christian fellow human beings are taken into account. Consensus, or De Kuijf's 'principles of cultural law', is sought in a liberal democracy. In De Kruijf's opinion on abortion this implies, amongst others, that (1) we acknowledge the right of women to decide and (2) the state has the duty of also protecting unborn human life.

A responsible approach in terms of the new constitution involves applying the golden rule. We do not wish to forcefully subject people of other persuasions to our beliefs because we also do not want to be subjected to the beliefs of others (cf. Huber in De Villiers 2007a:93).

\section{Ethical aspects of De Villiers's reflections on euthanasia}

De Villiers's (2002a, 2002b) contribution to the issue of euthanasia, amongst others, indicates how crucial different approaches to ethical issues are and how they can give rise to very different ethical judgements. To this end, De Villiers's (2002 a, 2002b) compares Harry Kuitert's 'thin' (Walzer) approach (stressing autonomy, technology broadens our responsibility, aimed at ethical consensus with others in respect of public policy, the admission of euthanasia for the relief of suffering) with Gilbert Mielander's 'thick' approach (focusing upon what is specifically Christian, the commandment 'thou shalt not kill', God gives and takes life, rejecting euthanasia and permitting only the conditional cessation of medical treatment). However, in this article, De Villiers (2002a, 2002b) does not, as is customary after the characteristic Christian viewpoint and consultation with other Christians (the 'thick' approach), follow up with perspectives for public debate from those of other persuasions (the 'thin' approach).

Yet, De Villiers's approach in this regard is problematic. The question of abortion is not treated as an ethical dilemma which has positive and negative motives and consequences, although it is conceded that extraordinary circumstances do 
arise in which assistance with suicide or euthanasia is the lesser of the two evils. Only the possible negative motives (the usefulness, cost-effectiveness, productivity) of the liberal ethicists are emphasised. Elsewhere, De Villiers (2006b) criticises the DRC's arguments on abortion on the grounds that the DRC perceives only the motives for ethical rejection and that it does not fully grasp the dilemma. Should we not need to reconsider - amidst the realities of the artificial prolongation of life through medical technology, overpopulation, a scarcity of resources, especially medical, paralysing medical costs for families, and so on - the tension between God as life-giver and our responsibility to minimise suffering?

\section{De Villiers's fundamental ethics provides guidelines for 'social' and 'personal' ethics}

\section{Application to social ethics}

De Villiers applied the implications of his fundamental ethics, his analysis of various ethical approaches and his advocacy of especially an ethics of responsibility more comprehensively to the fields of politics and economics than to 'personal' ethics. This was accompanied by an emphasis on the church as ethical role player. In this regard, De Villiers's choice and focus is justifiable in respect of least two challenges.

\section{The challenge posed by our formerly narrowed ethics practice}

I recall how a colleague from the Wesley tradition, Len Hulley, in an informal discussion years ago, judged Afrikaans Christians as having a strong type of 'micro-morality', yet lacking in 'macro-morality'. In contrast, English-speaking Christians were generally more aware of the injustices in the country, the dangers of racism and the need for human rights and a true democracy. However, their own morality regarding sexual conduct, alcohol and language use was poor, as opposed to that of the Afrikaner. Although oversimplified, this is indeed an indication of our inherited morality: 'missionary piety' and 'puritanical inclinations' of the Scottish tradition (Kinghorn 1986:58-59).

From another, yet more relevant, perspective David Bosch (1979:202-220) trenchantly summed up the paucity of missionary models. The shortcomings of the 'evangelical' - and 'ecumenical' models are described as a 'narrowed gospel' [verskraalde evangelie] (Christ is Lord of the church but not of the cosmos) and a 'watered-down gospel' [verwaterde evangelie] (redemption depends upon political justice). De Villiers's ethical work can be deemed to be a restoration of the true Reformed position; to broaden it without succumbing to dilution.

\section{The challenges posed by modernisation and the situation in a democratised South Africa}

There is a tendency amongst members of, amongst others, the DRC, as a result of a loss of power, affirmative action, being subjected to crime, and so on, to withdraw to their own convenient private bubble of personal relationships, private interests and religious experiences (De Villiers 2004:111). We are in need of the Social Sciences in order to understand the processes of modernisation, globalisation and secularisation to enable us play a public role in society and to assist in performing a transformational task (De Villiers 2004:117-118).

This also explains the need for the authentic ethical approaches in which De Villiers was for the most part engaged. Sufficient examples have already been given to indicate how De Villiers's fundamental questions and solutions assist us in fulfilling our moral obligations in the new political circumstances (such as the 'thick' and 'thin' processes described above).

\section{Application to 'personal' ethics}

De Villiers focused more on the fundamental-ethical than on the 'more personal ethical issues'. This fundamental accountability nevertheless holds very important implications for personal ethics, however one may define this term. If you build a firm foundation for your home, you make it possible and easier for others to build further and in line with that foundation.

\section{I refer only to some obvious implications:}

- Seeking a particular Christian morality assists us in grasping, at an individual level, the radical and universal character of the commandment to love our neighbour, whilst any content that corresponds to the morality of others renders collaboration with others desirable (cf. De Villiers 1978, especially pages 217-219).

- A process of differentiating in order to make ethical judgements essentially assists individuals - as it assists the church - in making more authentic decisions possible. Here I am reminded of articles on this matter, including those written in collaboration with Dirkie Smit (De Villiers \& Smit 1995, 1996).

- Advocating an ethic of responsibility and judging different versions (De Villiers 2006c, 2007a) provides direction to the development of responsibility amongst individuals, and especially their relationships. Such a strong 'personal' component existed from the start (Max Weber on the vocational responsibility of politicians, Dietrich Bonhoeffer on the responsibility of individuals in concrete situations and H.R. Niebuhr on 'The responsible self'). The approach makes a personal appeal - for example with a reference to Matthew 25 - that each person is ultimately answerable to God. De Villiers's (2006c) analysis of Hans Jonass's version, in which responsibility amounts to an independent normative principle, as opposed to, for example, Ulrich Körtner, who views responsibility as the concept that integrates the three aspects of values, duties and virtues (De Villiers 2007a), also assists individuals not to conceive of the ethic of responsibility as an ethic that lacks concrete guidelines.

One could do the same with De Villiers's other contributions (e.g. 'An ethic of peace' in 1989). However, it suffices to assert that De Villiers's fundamental contributions also provide significant implications for the terrain of more personal ethics. 


\section{Acknowledgements Competing interests}

The author declares that he has no financial or personal relationships which may have inappropriately influenced him in writing this paper.

\section{References}

Bonhoeffer, D., 1995, Ethics, Simon \& Schuster, New York.

Bosch, D.J., 1979, Heil vir die wêreld, NG Kerkboekhandel, Pretoria.

De Villiers, D.E., 1978, Die eiesoortigheid van die Christelike moraal, Rodopi, Amsterdam.

De Villiers, D.E., 1986, 'Kritiek uit die ekumene', in J. Kinghorn (red.), Die NG Kerk en Apartheid, pp. 144-164, Macmillian, Johannesburg.

De Villiers, D.E., 1989, 'Conceptions of peace in South Africa in the light of the biblical concept of peace', in K. Nürnberger, J. Tooke \& W. Domeris (eds.), Conflict and the quest for Justice - NIR Reader 2, pp. 117-129, Encounter, Pietermaritzburg.

De Villiers, D.E., 1996, 'Om geduldig te wees', in C.W. Burger, B.A. Müller \& D.J. Smit (red.), Riglyne vir prediking oor die Christelike deugde, pp. 184-193, Lux Verbi, Cape Town.

De Villiers, D.E., 1998, 'Christian views on cloning: Calvinist tradition', Proceedings of a Colloquium on Cloning, pp. 15-18, Department of Arts, Culture, Science and Technology, Pretoria.

De Villiers, D.E., 2002a, 'Euthanasia and assisted suicide: A Christian ethical perspective', ActaTheologica 22(3), 35-47.

De Villiers, D.E., 2002b, 'Who will bear moral responsibility?', Communicatio 28(1), 16-21. http://dx.doi.org/10.1080/02500160208537953
De Villiers, D.E., 2004, 'Religion, theology and the social sciences in a society of transition', Hervormde Teologiese Studie 60(1\&2), 103-124.

De Villiers, D.E., 2006a, 'Gee die Bybel nog vandag aan ons morele oriëntering oor kwessies soos homoseksualiteit?', ActaTheologica 26(1), 54-75.

De Villiers, D.E., 2006b, 'The official stance of the Dutch Reformed Church on abortion A Christian-ethical perspective', Tydskrif vir Christelike wetenskap 24(2), 73-89.

De Villiers, D.E., 2006c, 'Prospects of a Christian ethics of responsibility (Part 1): An assessment of an American version', Verbum et Ecclesia 27(2), 468-487.

De Villiers, D.E., 2007a, 'Prospects of a Christian ethics of responsibility (Part 2): An assessment of three German versions', Verbum et Ecclesia 28(1), 88-109.

De Villiers, D.E., 2007b, 'Kruispunte in Christene se besluitneming oor homoseksualiteit', in C. Vos \& D. Human (red.), Liefde is die grootste, pp. 282-289, Protea, Pretoria.

De Villiers, D.E., 2008, 'The interdependence of public witness and institutional unity in the Dutch Reformed family of churches', Verbum et Ecclesia 29(3), 728-743.

De Villiers, D.E. \& Smit D.J., 1995, “"Met watter gesag sê u hierdie dinge?” Opmerkings oor kerklike dokumente oor die openbare lewe', Skrif en Kerk 16(1), 39-56.

De Villiers, D.E. \& Smit D.J., 1996, 'Waarom verskil ons so oor wat die wil van God is? Opmerkings oor Christelike morele oordeelsvorming', Skrif en Kerk 17(1), 31-47.

Du Toit, D.A., 2008, 'Etiek, sosiale', in F. Gaum, A. Boesak \& W. Botha (red.), Christelike Kernensiklopedie, pp. 320-321, Lux Verbi, Wellington.

Heyns, J.A., 1982, Teologiese Etiek, deel 1, NG Kerkboekhandel, Pretoria.

Heyns, J.A., 1986, Teologiese Etiek, deel 2/1, NG Kerkboekhandel, Pretoria.

Jones, C., 2008, 'Etiek, persoonlike', in F. Gaum, A. Boesak \& W. Botha (red.), Christelike Kernensiklopedie, pp. 318-319, Lux Verbi, Wellington.

Kinghorn, J., 1986, 'Vormende faktore', in J. Kinghorn (red.), Die NG Kerk en Apartheid, pp. 47-68, MacMillian, Johannesburg.

Nürnberger, K., 1984, Theological ethics, University of South Africa, Pretoria.

Praamsma, L., 1981, De Kerk van alle tijden, deel 4, Wever, Franeker. 